\title{
Textile Industry a Tool of Economics Development in District Muzaffargarh (Pakistan)
}

\author{
Sohail Akhtar Sakhani* \\ Department of History, Ghazi University, Pakistan \\ *Corresponding author: Sohail Akhtar Sakhani, Department of History, Ghazi University, Dera Ghazi Khan, Pakistan
}

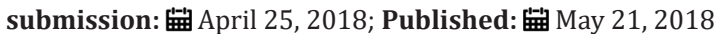

\begin{abstract}
Before the British rule the district mostly remained under the Multan province. Many dynasties ruled at the district. Langah, Nahars, Baloch and Sadozai families. After them Sikhs was in power and they occupied the district in 1818. After the Sikh the British occupied the Punjab in 1849. Now Dera Ghazi Khan was under the rule of British administration. The district has seen lot of changes in his history. Muzaffargarh is thought a backward district of Punjab in Pakistan. Progress and prosperity of an area depends on the socio-economic climate prevailing with in the country. Economic condition determines and influences the social progress and the standard of the living of the people. The economic condition does not stay same. It is constantly fluctuating and changing for good or bad. In fact economic development and social progress are important for each others. Pakistan is an important agricultural country. This paper is concerning to a small region Muzaffargarh District. The district is geographically located between the two river Indus and Chenab. Therefore, the district is very rich for agriculture. Almost all kinds of crops are cultivated but cotton and wheat are major crops of the district. Due to the availability of water agriculture is a common profession of the people of the region. The production of cotton raw material in enough quantity is very valuable for the textile industry because it is very important source of the economy. It is a source of foreign exchange. Muzaffargarh district was backward in industrial point of view. There was nothing industrial development before the establishment of Pakistan. The district had not taking any advantage in the development of industries from its neighboring district Multan and industrial potential was not seen in the district till 1960. But the trend about the foundation of textile industry rose gradually to climax. In the district, the existence of a large number of textile industry supported human development. This paper highlights the importance of textile industry in the economic development of Muzaffargarh District.
\end{abstract}

Keywords: Agriculture; Cotton; Textile; Industry; Muzaffargarh; Pakistan, etc.

\section{Discussion}

They established new administrative zones as divisions and districts. Layyah was made as a divisional head quarter, While Khangarh was declared as a district of Layyah division. In 1861 Layyah lost its divisional and district status and Muzaffargarh was declared as a district in place of Khangarh [1]. In 1909 Tehsil Layyah became a part of district Muzaffargarh. In 1947, administratively Muzaffargarh became a part of Bahawalpur State but at the end of one unit Muzaffargarh district added in Multan division. Muzaffargarh is situated between the two rivers Indus and Chenab. It has populated from many centuries. The district has fertile land and the natural sources of water are available here [2].

On 1st July 1982 Dera Ghazi Khan was announced as a new division, Layyah Tehsil was upgrade as district and both the districts Muzaffargarh and Layyah became the part of Dera Ghazi Khan Division [3]. The Taunsa Head works project has played an important role in the development of the Thal area of the tehsil. The barrage across the river Indus 12 liles down stream of Taunsa on a line along 30 to 32 degree latitude. It is playing a vital role in the economy of the district [4].
Agriculture is the main occupation of the people in Pakistan while the people are living in district Muzaffargarh which is a poor region in Pakistan agriculture is an important profession of majority. Allah has gifted vast plain, suitable climate condition and better irrigation facilities to the people of the district. The plain areas of Muzaffargarh consist of upon the latest irrigation canal system. People cultivated their lands with latest technology of modern demands and produced all typed of crops and vegetables [5]. Cotton is one of the most important cash crops of the district. It is cultivated in vast area of the district and the best crop of cotton is cultivated in the district. The cotton of Alipur is most splendid in whole Pakistan; therefore the district is very rich in the agriculture sector. The latest irrigation system fertile plains and the suitable climate increasing its production. Large numbers of textile industries were established due to the better production and availability of raw material. It is not only used for the manufacturing of cloth besides the preparation of a number of its products, but also earns a large amount of foreign exchange. It is natural fiber, its color is being mostly white and it is also known as silver fiber 
[6]. Cotton is cultivated in the whole district naturally 30 " to 40" inches annual rainfall is sufficient for its growth, but in the district the annual rain fall is less than 10" inches which is insufficient for its production. Therefore, without artificial irrigation facilities its cultivation is not possible. But it is seen that too much water is also dangerous for this crop. In the cultivation of this crop, alluvial soil is more suitable for its growth. The soils having a mixture of clay and sand give fantastic result. It is cultivated in mostly dry areas of the district. It is a crop of summer season and its duration is april to september. In the district cotton is cultivated on domestic bases and it has two main forms, the American and the Desi quality of cotton. The district produces surplus quantity of cotton therefore after local requirement remaining cotton is exported to the other areas or foreign countries [7].

That Limited formerly That Jute Mills enjoys the distinction of being the pioneer industrial project of the House of Habib The project was launched and the name of Thal Jute Mills Limited name has been changed to Thal limited. The changed name has been approved by the Registrar of Companies. Thal Mills is engaged in the manufacture of jute goods. It is also involved in assembly and manufacture of engineering goods. Jute Mills Limited was awarded export merit trophies for their export performance by the Government (Table 1; $[8,9]$ ).

Table 1:

\begin{tabular}{|c|c|c|}
\hline Looms & Spindles & Capacity Of Production (in Tones) \\
\hline 300 & 4064 & 16000 \\
\hline
\end{tabular}

Cotton industry is considered as a very important industry of the district. In 1973 the industry was nationalized and a corporation was established to control and manage all the nationalized ghee factories of the country. After this a ghee factory was established in the district. But its work was on very small scale. According to the census report of 1981 there were 65 important industrial units of cotton ginning, pressing, and Sugar and cotton textile. Some important industries are as following [10].

The district was a very back ward area of the country and in the beginning there were very few industries due to the shortage of skilled persons. It was necessary to run any new industry skilled labor must be required. Therefore lack of engineers \& skilled technician were necessary to work a new industry but it was a big asks these days to establish a new industry and run it. The district was also back ward for the technical and scientific point of view. Education was very less and people were illiterate from the modern and scientific knowledge especially in the field of technology. Different policies of the various Governments also effect the industrial development. Due to the political \& administrative changes the people particularly industrialists' persons lost their confidence therefore they do not take interest for investment to establish a new industry. For industrial development it is necessary to build up the confidence of the businessmen. Government encouraged the private sector as well as public sector, for this Govt. took step and established an industrial development corporation.
It was asked to establish various industries in the country so that local raw material and other resources available could be utilized. This corporation worked to establish new industries but in Muzaffargarh the backwardness of the district was more effective and the district could not make a sufficient progress in industrial sector, all the attention was only on agriculture sector. According to the survey of the board of inquiry there were only 13 factories which employed more than 50 laborers compared with 2640 in the old Punjab [11].

The above Table 2 shows the trend of cotton industry in the district the most important is that this trend is completely increasing rapidly. The district has become now important centre of textile industry.

Table 2:

\begin{tabular}{|c|c|}
\hline S. No. & Name of Industries \\
\hline 1 & Amin Textile Mills Muzaffargarh \\
\hline 2 & Budha Ram \& co., Cotton factory, Khangarh \\
\hline 3 & Itfaq Hosiery \& Textile Mills Muzaffargarh \\
\hline 4 & Shree Parshad \& CCo.Cotton Factory Muzaffargarh \\
\hline 5 & Siraj \& Co. Cotton Ginning Factory Khangarh. \\
\hline 6 & Zaffar Cotton factory, Khangarh \\
\hline 7 & Layyah Sugar Mills Layyah \\
\hline 8 & Mistry Aurangzeb Flour Mills, Khangarh \\
\hline 9 & Pak Ice Factory, M.Garh \\
\hline 10 & Thal Jute Mills Ltd Muzaffargarh \\
\hline 11 & Khokhar textile Mills Chowk Sarwar Shaheed \\
\hline 12 & Madina Jute mills Ltd Muzaffargarh \\
\hline 13 & Imperial textile mills Muzaffargarh \\
\hline 14 & Indus dying factory Muzaffargarh \\
\hline 15 & Fatima sugar mills Muzaffargarh \\
\hline 16 & Sun-rays textile mill Muzaffargarh \\
\hline 17 & Masood weaving mills Muzaffargarh \\
\hline 18 & Mahmood textile mills Muzaffargarh \\
\hline 19 & Aziz spinning textile Muzaffargarh \\
\hline 20 & Nafees textile mills Muzaffargarh \\
\hline 21 & Habib package factory Muzaffargarh \\
\hline 22 & Fatima textile mills Muzaffargarh \\
\hline 23 & Kamran flour mills Muzaffargarh \\
\hline 24 & Mohib textile mills Muaffargarh \\
\hline 25 & Pak Arab Oil Refinery Mahmood kot \\
\hline 26 & Apollo textile mills Muzaffargarh \\
\hline 27 & Lasani Ghee mills Muzaffargarh \\
\hline 28 & Tata textile mills Muzaffargarh \\
\hline
\end{tabular}

\section{Conclusion}

This paper very clearly highlights the economic value of textile engineering in Muzaffargarh which is a poor region and its economy 
is based on agriculture. Agriculture is the main occupation of the people of the district. Seventy percent population of the district is living in country sides and played a vital role in the economic development of the district. Although the per capita income is low from agriculture but a large numbers of people of the district are still engaged in this profession. Almost all kinds of crop are cultivated in the district. But cotton is the major crop of the district because a cash crops. During the colonial government there was lack of industry but with the passage of time in the district textile industry has very much improved. Several new units are being established.

\section{References}

1. District gazetteer (1929) District gazetteer Muzaffar Garh, Pakistan. p. 1.

2. District gazetteer (1929) District gazetteer Muzaffar Garh, Pakistan. p. 2.
3. Abdul Hamid Bhatto (1986) Biographic, encyclopedia of Punjab. Rahimyar Khan, Pakistan, p. 113.

4. Abdul QL, Tareekh DGK (2005) Salman academy p. 236.

5. Akbar SM (1970) Economics of Pakistan. p. 64.

6. (1964) District gazetteer Muzaffargarh, Pakistan. p. 134.

7. Sohail Akhtar Socio political and economic development in district Muzaffargarh, Pakistan. p. 4.

8. (2008) District Muzaffargarh, Pakistan. Census Report.

9. Progress report of thal jute mill, Muzaffargarh.

10. (2008) Census report district Muzaffargarh, Pakistan. p. 18.

11. Budh KM Jadeed Tareekh Muzaffargarh, Pakistan. p. 206.
Creative Commons Attribution 4.0 International License

For possible submissions Click Here

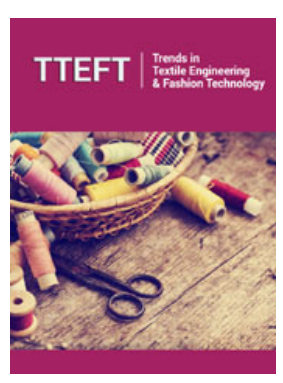

Trends in Textile Engineering \& Fashion Technology

\section{Benefits of Publishing with us}

- High-level peer review and editorial services

- Freely accessible online immediately upon publication

- Authors retain the copyright to their work

- Licensing it under a Creative Commons license

- Visibility through different online platforms 